\title{
Joint International Evaluation of Milking Shorthorn Dairy Cattle for Production Traits
}

\author{
R. Barrett, ${ }^{1}$ F. Miglior, ${ }^{2,3}$ G. Jansen, ${ }^{1}$ J. Jamrozik, ${ }^{1}$ and L. R. Schaeffer ${ }^{1}$ \\ ${ }^{1}$ Centre for the Genetic Improvement of Livestock, University of Guelph, Guelph, ON, Canada N1G 2W1 \\ ${ }^{2}$ Agriculture and Agri-Food Canada-Dairy and Swine Research and Development Centre, \\ Lennoxville, QC, Canada J1M 1 Z3 \\ ${ }^{3}$ Canadian Dairy Network, Guelph, ON, Canada N1G 4T2
}

\section{ABSTRACT}

Pedigree information and test-day records for the first 3 parities of Milking Shorthorn dairy cattle from 5 countries were analyzed. After editing, the data included 1,018,528 test-day records from 68,653 cows. A multiple-lactation random regression test-day model with Legendre polynomials of order 4 and a Bayesian method were used to estimate variance components for both single and multiple-countries. Fixed effects included herd-test-day class and regressions on DIM within age at calving-parity-season of calving. Random effects included animal genetic, permanent environmental, and residual effects. Average daily heritabilities from single country analyses ranged from 0.33 to 0.47 for milk yield and from 0.37 to 0.45 for protein yield across lactations and countries. Common sires (66) and their daughters were identified for creating a connected data set for simultaneous (co)variance component estimation of milk yield across all 5 countries. Between-country genetic correlations were low, with values from 0.08 to 0.46 and standard deviations from 0.08 to 0.12 . Estimated breeding values for milk were generated for each animal using the same test-day animal model. Correlations among country estimated breeding values were higher than genetic correlations. Top 100 bull lists were generated on the scale of each country, and genetic progress was assessed. Future evaluation with increased genetic ties among countries may facilitate international comparison of Milking Shorthorns.

(Key words: Milking Shorthorn, international evaluation, test-day model, genetic correlation)

Abbreviation key: INTERBULL = International Bull Evaluation Service, MACE $=$ multiple-trait acrosscountry evaluations.

Received January 5, 2005.

Accepted May 5, 2005.

Corresponding author: Filippo Miglior; e-mail: miglior@cdn.ca.

\section{INTRODUCTION}

International evaluation has become increasingly important in the field of genetic improvement of dairy cattle. Several studies have proven that international evaluations can increase the rate of genetic gain, especially in countries of lower mean genetic merit. Banos and Smith (1991) found that sire selection across 2 populations with identical breeding goals, equal population size, and equal genetic mean could increase genetic response by 7 to $17 \%$. Lohuis and Dekkers (1998) used simulated populations and found that the rate of genetic response increased to $17 \%$ under global selection across 3 equal populations when the genetic correlation between countries was unity. Genetic response could be higher in countries with lower genetic means or smaller populations by using internationally evaluated sires, but a decrease in genetic correlations diminishes the increase in genetic response.

On an individual producer level, evaluation of international sires may expose dairy farmers to sires from other countries, potentially offering genetic advantages for their particular production system. A multinational genetics company may benefit by having more data, which will help to sell their product both domestically and internationally. Use of international sires may also provide sources of unrelated genetic lines to combat inbreeding.

International evaluation of dairy sires has been performed for over a decade in several breeds by the International Bull Evaluation Service Center (INTERBULL) in Sweden. Since its adoption, international evaluation has been accomplished using precalculated, within-country EBV. Since 1995, these evaluations have been performed by INTERBULL using the multiple-trait across-country evaluation (MACE) method by Schaeffer (1994). A sire model, incorporating national evaluations in terms of de-regressed proofs, and expressing the international proof on each national scale, is used by MACE.

International evaluation has been a valuable tool for several years, but there are still several possible improvements which could be gained, particularly con- 
cerning sensitivity to genotype by environmental interaction, broadening of information sources, and proper reflection of within country industry structure (Schaeffer et al., 2000). Although MACE methodology is still used by INTERBULL for international evaluation of dairy sires, research continues on improved methods using actual production data from several countries for evaluation instead of de-regressed sire proofs, thereby addressing the continued reliance on national genetic evaluations. International evaluation using performance records is known as joint evaluation. In a study by Fikse (2002), in which 3 country populations and 2 production environments were simulated, selection bias was twice as high for evaluation using MACE than for evaluation using performance records in an animal model. Similarly, Sullivan (2002) found that use of a "global animal model" (a proposed method of borderless international evaluation) rather than other evaluation methods resulted in the largest decreases in standard error of prediction and biases with respect to increasing levels of semen exchange across countries.

With recent advances in computing capabilities, it has become possible to examine other methods of international evaluation; specifically, the use of test-day models based on actual test-day yields for genetic evaluation, thereby potentially increasing the amount of information available across countries. Test-day models are being used for national evaluation in several countries, and research has been conducted on their use for international evaluation. In a study by Jamrozik et al. (2002a), more than 32 million first-lactation Holstein test-day records from 4 countries (Italy, Canada, New Zealand, and Australia) were evaluated using a multiple-trait test-day model where "traits" were defined as countries. More recently, Pedersen et al. (2004) have developed a joint evaluation for 3 Scandinavian countries using a multiple-trait, multiple lactation, testday model.

International evaluations by INTERBULL have not yet included the Milking Shorthorn dairy breed. Milking Shorthorns are one of the oldest established dairy breeds in the world, and the breed has been increasing in popularity in several countries. Milking Shorthorns are present in several countries, with sizeable populations and active breed associations in Australia, Canada, Great Britain, New Zealand, and the United States. The Illawarra breed is identified as "Milking Shorthorn" in Australia, as is the Dairy Shorthorn population in Great Britain. Milking Shorthorns can be red, white, or roan in color, and have recently moved away from being a dual-purpose breed to embracing outside genetics to improve dairy type and milk production levels.
The primary objective of this study was to develop a method of joint evaluation of production traits for the Milking Shorthorn breed using a multiple-lactation, multiple-country test-day model for 5 countries with populations of Milking Shorthorn-type cattle. Secondary objectives of this research included the determination of genetic ties among countries in the study, estimation of within- and across-country genetic parameters, and determination of various production parameters in the different dairy production systems.

\section{MATERIALS AND METHODS}

Test-day data from the first 3 lactations and pedigree information were provided by national genetic evaluation centers from 5 countries: Australian Dairy Herd Improvement Scheme (ADHIS, Australia), Canadian Dairy Network (CDN, Canada), Milk Development Council Evaluations (MDC, Great Britain), Livestock Improvement Corporation (LIC, New Zealand), and Animal Improvement Programs Laboratory (AIPL, United States). The 5 participating countries represented a wide range of production systems and genetic compositions. Australia had the largest population of cows with records $(38,533)$, and Canada had the smallest (1235). The following edits were applied to the original data: records from animals without identified sires were deleted, test-day records less than 5 DIM or greater than 305 DIM were deleted, age in months was restricted to between 18 and $63 \mathrm{mo}$, and records from cows born before 1985 were excluded from the data to place cows from all countries on a similar reference level. Additionally, parity number for records from Australia and Great Britain had to be enforced using age at calving and the number of calving dates in the data, due to concerns of data validity. Total size of data after editing from the 5 countries for single-country parameter estimation of milk and protein yield was 1,018,528 records and 68,653 cows with records (Table 1 ). The actual number of records and cows for protein yield was slightly lower than for milk.

Pedigree files from the 5 countries were consolidated into an international pedigree file, and a unique crossreference file was also assembled for animals with duplicated registration numbers in more than one country. Connectedness was measured by number of common sires and daughters and granddaughters of common sires. A common sire was defined as having at least 5 daughters and granddaughters in 2 or more countries (5 in each country). A list of common sires was generated, as well as a list of their daughters and granddaughters. Using this list of "common daughters and granddaughters," the percentage of cows in each herd comprised of these "common cows" was calculated, 
Table 1. Number of records, cows, and pedigree animals in the 5 countries used for single-country variance component estimation.

\begin{tabular}{lrrrrrrr}
\hline & \multicolumn{3}{c}{ Milk } & & \multicolumn{3}{c}{ Protein } \\
\cline { 2 - 4 } \cline { 7 - 8 } & Records & Cows & Pedigree & & Records & Cows & Pedigree $^{1}$ \\
\hline Australia & 607,655 & 38,533 & 57,948 & & 604,770 & 38,492 & 57,859 \\
Canada & 17,802 & 1235 & 3169 & & 17,151 & 1201 & 3169 \\
Great Britain & 155,134 & 9154 & 18,161 & & 155,134 & 9154 & 18,161 \\
New Zealand & 61,439 & 7056 & 12,635 & & 61,425 & 7055 & 12,634 \\
United States & 176,498 & 12,675 & 28,103 & & 162,338 & 12,199 & 27,599 \\
\hline
\end{tabular}

${ }^{1}$ Includes cows with records.

and these percentages were used to select "common herds" by country, according to threshold values set for each country. Distribution of herds chosen per country was generally proportional to total contribution to data set, with the countries having smaller population sizes having slightly more representation, in an effort to ensure that all 5 countries were meaningfully represented. The threshold values were $75 \%$ for the United States, $80 \%$ for Canada, 30\% for New Zealand, 55\% for Australia, and $25 \%$ for Great Britain. Threshold values were markedly lower for Great Britain, New Zealand, and Australia because of the smaller number of "common daughters and granddaughters" present in those countries. All records per herd were then aggregated for the 131 selected herds and used for multiple-country parameter estimation. This data set had a total of 156,574 test-day records and 11,056 cows with records across the 5 countries (Table 2).

Single and multiple-country parameter estimation by Bayesian methods were completed using a random regression test-day animal model and Gibb's sampling. Single country variance component estimation for milk and protein yield was conducted on single-country data sets $(1,018,528$ records), whereas multiple-country variance component estimation was performed on the data set generated from the 131 connected herds

Table 2. Number of records, cows, and herds used for multiplecountry variance component and breeding value estimation for milk yield.

\begin{tabular}{lrrr}
\hline & \multicolumn{1}{c}{ Records } & \multicolumn{1}{c}{ Cows } & Herds \\
\hline Variance components, total & 156,574 & 11,056 & 131 \\
Australia & 56,292 & 3497 & 42 \\
Canada & 14,086 & 963 & 17 \\
Great Britain & 17,773 & 1061 & 11 \\
New Zealand & 18,705 & 2138 & 24 \\
United States & 49,718 & 3397 & 37 \\
Breeding values, total & $1,018,528$ & 70,196 & 1641 \\
Australia & 607,655 & 38,533 & 596 \\
Canada & 17,802 & 1333 & 67 \\
Great Britain & 155,134 & 9380 & 100 \\
New Zealand & 61,439 & 7473 & 219 \\
United States & 176,498 & 13,477 & 659 \\
\hline
\end{tabular}

(156,576 records). Variance components among countries were estimated for milk yield only.

The model used for the within-country parameter estimation can be expressed in matrix notation by the equation:

$$
\mathrm{y}_{\mathrm{m}}=\mathrm{H}_{\mathrm{m}} \mathrm{h}_{\mathrm{m}}+\mathrm{X}_{\mathrm{m}} \mathrm{b}_{\mathrm{m}}+\mathrm{W}_{\mathrm{m}} \mathrm{p}_{\mathrm{m}}+\mathrm{Z}_{\mathrm{m}} \mathrm{u}_{\mathrm{m}}+\mathrm{e}_{\mathrm{m}}
$$

where $\mathbf{y}_{\mathbf{m}}$ is a vector of observations from lactations 1 , 2 , and 3 , for country $\mathrm{m}(\mathrm{m}=1, \ldots, 5) ; \mathbf{h}_{\mathrm{m}}=$ is a vector of fixed herd-test-day effects; $\mathbf{b}_{\mathbf{m}}=$ is a vector of fixed regression coefficients for age/parity/season of calving effects (parity number enforced for British and Australian data); $\mathbf{p}_{\mathbf{m}}=$ is a vector of random regression coefficients for permanent environmental effects; $\mathbf{u}_{\mathbf{m}}=$ is a vector of random regression coefficients for animal genetic effect; $\mathbf{e}_{\mathbf{m}}=$ is a vector of residuals; and $\mathbf{H}_{\mathrm{m}}$, $\mathbf{X}_{\mathbf{m}}, \mathbf{W}_{\mathbf{m}}$, and $\mathbf{Z}_{\mathbf{m}}$ are incidence matrices assigning observations to effects.

The across-country model was:

$$
\mathrm{y}=\mathrm{Hh}+\mathrm{Xb}+\mathrm{Wp}+\mathrm{Zu}+\mathrm{e}
$$

where

$$
\begin{aligned}
& \mathbf{y}=\left[\begin{array}{llll}
\mathbf{y}_{1}{ }^{\prime} & \ldots & \mathbf{y}_{5}{ }^{\prime}
\end{array}\right]^{\prime}, \mathbf{h}=\left[\begin{array}{llll}
\mathbf{h}_{1}{ }^{\prime} & \ldots & \mathbf{h}_{5}{ }^{\prime}
\end{array}\right]^{\prime}, \mathbf{b}=\left[\begin{array}{llll}
\mathbf{b}_{1}{ }^{\prime} & \ldots & \mathbf{b}_{5}{ }^{\prime}
\end{array}\right]^{\prime}, \\
& \mathbf{p}=\left[\begin{array}{lll}
\mathbf{p}_{1}{ }^{\prime} & \ldots & \mathbf{p}_{5}{ }^{\prime}
\end{array}\right]^{\prime}, \\
& \mathbf{a}=\left[\begin{array}{lll}
\mathbf{a}_{1}{ }^{\prime} & \ldots & \mathbf{a}_{5}{ }^{\prime}
\end{array}\right], \mathbf{e}=\left[\begin{array}{lll}
\mathbf{e}_{1}^{\prime} & \ldots & \mathbf{e}_{5}{ }^{\prime}
\end{array}\right], \\
& \mathbf{H}=\boldsymbol{\Sigma}^{+} \mathbf{H}_{\mathrm{i}}, \mathbf{X}=\boldsymbol{\Sigma}^{+} \mathbf{X}_{\mathrm{i}} \text { (direct sum of matrices). }
\end{aligned}
$$

Regression curves were modeled using Legendre polynomials of order 4 , defined as:

$$
\begin{aligned}
& \mathbf{Z}_{\mathbf{t} \mathbf{0}}=1.0 \\
& \mathbf{Z}_{\mathbf{t} \mathbf{1}}=3.0^{0.5} \mathbf{x} \\
& \mathbf{Z}_{\mathbf{t} \mathbf{2}}=5.0^{0.5}\left(1.5 \mathrm{x}^{2}-0.5\right) \\
& \mathbf{Z}_{\mathbf{t} \mathbf{3}}=7.0^{0.5}\left(2.5 \mathrm{x}^{3}-1.5\right), \\
& \mathbf{Z}_{\mathbf{t} \mathbf{4}}=9.0^{0.5}\left(35 \mathrm{x}^{4}-30 \mathrm{x}^{2}+3\right) / 8
\end{aligned}
$$

where $\mathrm{x}=2(\mathrm{t}-5) / 300-1$ is standardized time, and $\mathrm{t}$ is DIM (5 to $305 \mathrm{~d}$ ). 
Table 3. Average raw 24-h milk yield, and fat and protein percentage in the 5 countries.

\begin{tabular}{|c|c|c|c|c|c|c|}
\hline & \multicolumn{6}{|c|}{ Average 24 -h production } \\
\hline & \multicolumn{2}{|c|}{ Milk yield, kg } & \multicolumn{2}{|c|}{ Fat $\%$} & \multicolumn{2}{|c|}{ Protein \% } \\
\hline & Mean & SD & Mean & SD & Mean & $\mathrm{SD}$ \\
\hline Australia & 15.3 & 6.2 & 3.79 & 0.71 & 3.29 & 0.42 \\
\hline Canada & 20.2 & 7.1 & 3.69 & 0.68 & 3.40 & 0.35 \\
\hline Great Britain & 17.9 & 6.1 & 3.93 & 0.60 & 3.34 & 0.32 \\
\hline New Zealand & 12.8 & 4.9 & 4.45 & 0.81 & 3.68 & 0.43 \\
\hline United States & 21.1 & 7.7 & 3.64 & 0.72 & 3.32 & 0.40 \\
\hline
\end{tabular}

Expectations and covariance structure for random effects can be described in matrix notation as

$$
\mathrm{E}(\mathrm{y})=\mathrm{Hh}+\mathrm{Xb}, \mathrm{E}(\mathrm{p})=0, \mathrm{E}(\mathrm{u})=0, \mathrm{E}(\mathrm{e})=0
$$

and

$$
\mathrm{V}(\mathbf{p})=\mathbf{P}, \mathrm{V}(\mathbf{a})=\mathbf{G}, \mathrm{V}(\mathbf{e})=\mathbf{E},
$$

where $\mathbf{P}=\mathbf{I} \otimes \mathbf{P}_{\mathbf{0}}, \mathbf{G}=\mathbf{A} \otimes \mathbf{G}_{\mathbf{0}}$ (direct product of matrices), $\mathbf{A}$ is the additive relationship matrix, and $\mathbf{P}_{0}$ and $\mathbf{G}_{0}$ are $75 \times 75$ covariance matrices for environmental and genetic regression coefficients, respectively. All between-country covariances in $\mathbf{P}_{0}$ were equal to zero. Finally, $\mathbf{E}$ is a diagonal residual covariance matrix consisting of different variances for each combination of parity and interval of day in milk. These intervals were defined as 5 to 45,46 to 115,116 to 205 , and 206 to 305 DIM.

For all Bayesian-based methods in this study, random effects of the model were normally distributed, and the conditional distribution of the data was normal. In addition, residual effects were assumed independent.

Single-country parameter estimation was run for 120,000 Gibbs samples after a 20,000-sample burn-in, whereas multiple-country estimation was run for 20,000 samples after a 10,000-sample burn-in.

Single chains of 140,000 samples (with 20,000 discarded) were generated for each single-country model. Flat prior distributions were assumed for all fixed effects. For genetic and PE effects, normal prior distributions were used. Priors for covariances were as estimated previously from Canadian Milking Shorthorn data (Muir and Kistemaker, 2003). For the multiplecountry model, a chain of 30,000 samples (with 10,000 as burn-in period) was generated.

Breeding values for milk yield were estimated using a multiple-country multiple-lactation random regression test-day animal model on a complete data set from the 5 countries (Table 1). The model for breeding value estimation was equivalent to the model used for param- eter estimation with the addition of genetic groups, defined by country, sex, and year of birth.

Mixed model equations were solved iteratively for 1000 rounds of iterations. The conversion criteria of sum of squares between new and old solutions divided by the sum of squares of the new solutions was less than $5.0 \times 10^{-8}$ for all analyses. Correlations among estimated breeding values were computed. Genetic trends over time were calculated by averaging estimated breeding values across lactations and across country scales, and expressed in standard deviation units. Top 100 lists of bulls for each country scale were also generated. Country of bull origin was assumed as the country with the largest number of daughters.

\section{RESULTS AND DISCUSSION}

\section{Production Systems}

Average 24-h milk yield and fat and protein percentages for first 3 lactations in the 5 countries are shown in Table 3. New Zealand was characterized by much lower milk yield and higher milk solid percentages. The other 4 countries tended to have similar milk solid percentages, and differed primarily in milk yield. Canada and the United States had very similar average daily milk yields, which was expected based upon the similarity of production systems and genetic influence in the 2 countries. Great Britain had an average daily milk yield approximately $2 \mathrm{~kg}$ lower than North American countries, and the Australian population average was intermediate between Great Britain and New Zealand. Pasture is traditionally the primary feed source for dairy cattle in Australia and New Zealand, and this is the case for Milking Shorthorn herds in Great Britain (F. Milnes, personal communication, 2004). Consequently, smaller daily milk yields would be expected in those 3 countries.

The data structure of the 5 countries is described in more detail in Table 4. Herds in Australia had the largest average herd size, with the other countries having similar averages but varying standard deviations. 
Table 4. Data structure in the 5 countries.

\begin{tabular}{|c|c|c|c|c|c|c|c|c|}
\hline & \multicolumn{2}{|c|}{ Herd size } & \multicolumn{2}{|c|}{ Obs./HTD ${ }^{1}$ group } & \multicolumn{2}{|c|}{ TD $/$ Cow/Parity } & \multicolumn{2}{|c|}{ Daughters/Sire } \\
\hline & Mean & SD & Mean & SD & Mean & SD & Mean & $\mathrm{SD}$ \\
\hline Australia & 45.2 & 90.5 & 12.9 & 15.7 & 7.6 & 2.2 & 16 & 46.7 \\
\hline Canada & 20.6 & 40.5 & 6.8 & 8.1 & 7.2 & 2.6 & 8.7 & 16 \\
\hline Great Britain & 28.3 & 61.4 & 10.2 & 14.4 & 8.7 & 1.9 & 15 & 71.9 \\
\hline New Zealand & 21.0 & 63.1 & 11.7 & 22.1 & 4.1 & 1.7 & 13 & 29.3 \\
\hline United States & 17.1 & 59.8 & 7.5 & 13.7 & 6.9 & 2.8 & 10.2 & 28.7 \\
\hline
\end{tabular}

The low average herd size in Canada, New Zealand, and United States was mainly due to the Milking Shorthorn breed being the minority in mixed breed herds. Australia had the highest number of records per herd-testday class at 12.9, whereas Canada and the United States both had averages less than 10. Standard deviation of records per herd-test-day class was largest in the New Zealand population, potentially due to some very large herds with many contemporaries along with other herds containing only a few Milking Shorthorn animals. For all countries, these values were lower than class sizes in other studies, such as that in Jamrozik et al. (2002b), where the average number of Holstein first-lactation test-day records per herd-test-day class was 9.8 for Canada, 13.3 for Italy, 19.8 for Australia, and 24.6 for New Zealand. There was a marked difference between New Zealand at 4.1 test-day records per cow per parity and the other 4 countries, which all had values of more than 6.9. This reflects both the seasonal production practices and the less frequent herd testing in New Zealand. Average number of daughters with records per sire was small in all 5 countries, especially in Canada and the United States. This was likely due to substantial use of natural service sires and privately sampled AI sires in these 2 countries. Great Britain had the second highest average number of daughters per sire at just over 15, but the largest standard deviation. This may indicate the heavy usage of some AI sires, but the continued usage of natural service herd sires with few daughters. Average numbers of daughters per sire were less than 16, as only Australia and Great Britain have progeny testing programs of any appreciable size.

Milk production in first lactation was plotted by DIM for each country (Figure 1). Milk production curves for Canada, the United States, and Great Britain were

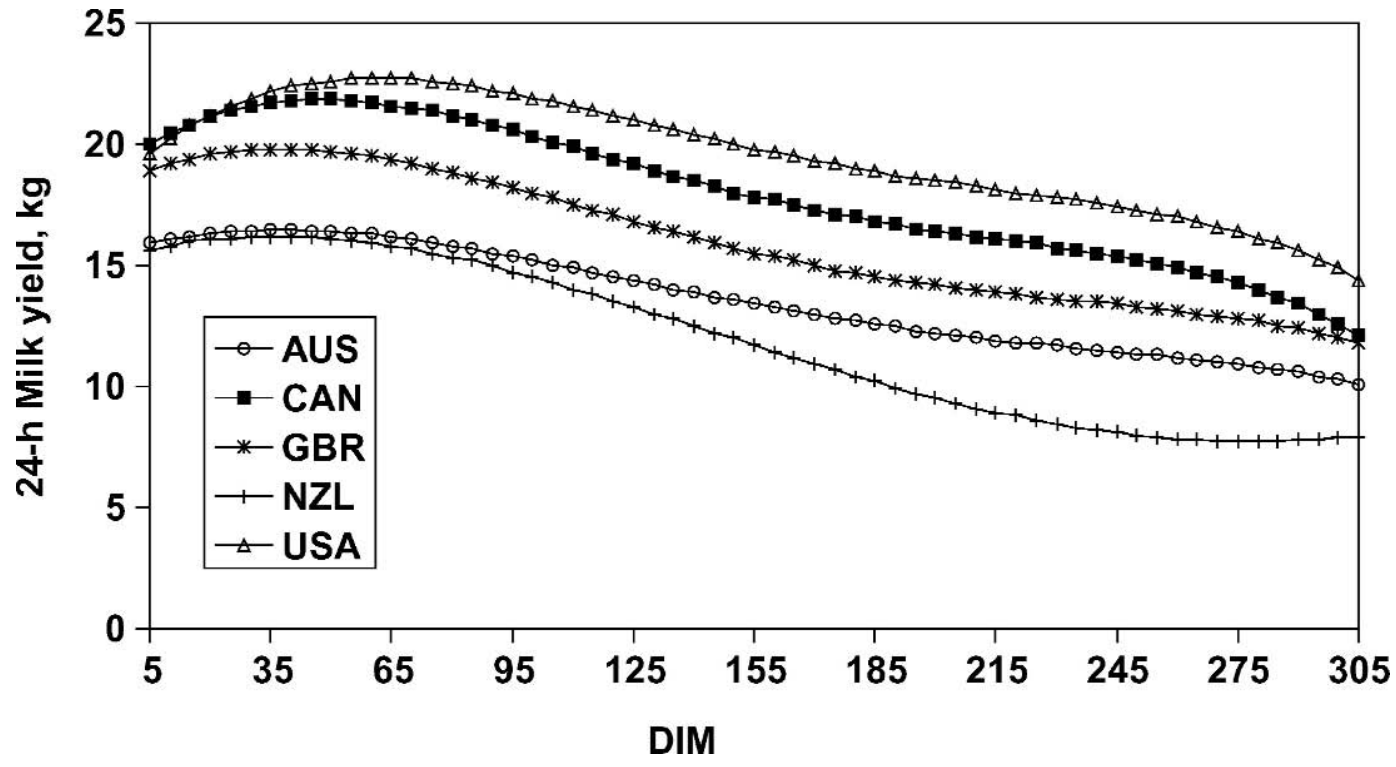

Figure 1. Lactation curves for milk yield by DIM in first lactation for the 5 countries. AUS = Australia; CAN = Canada; GBR = Great Britain; NZL = New Zealand; USA = United States. 


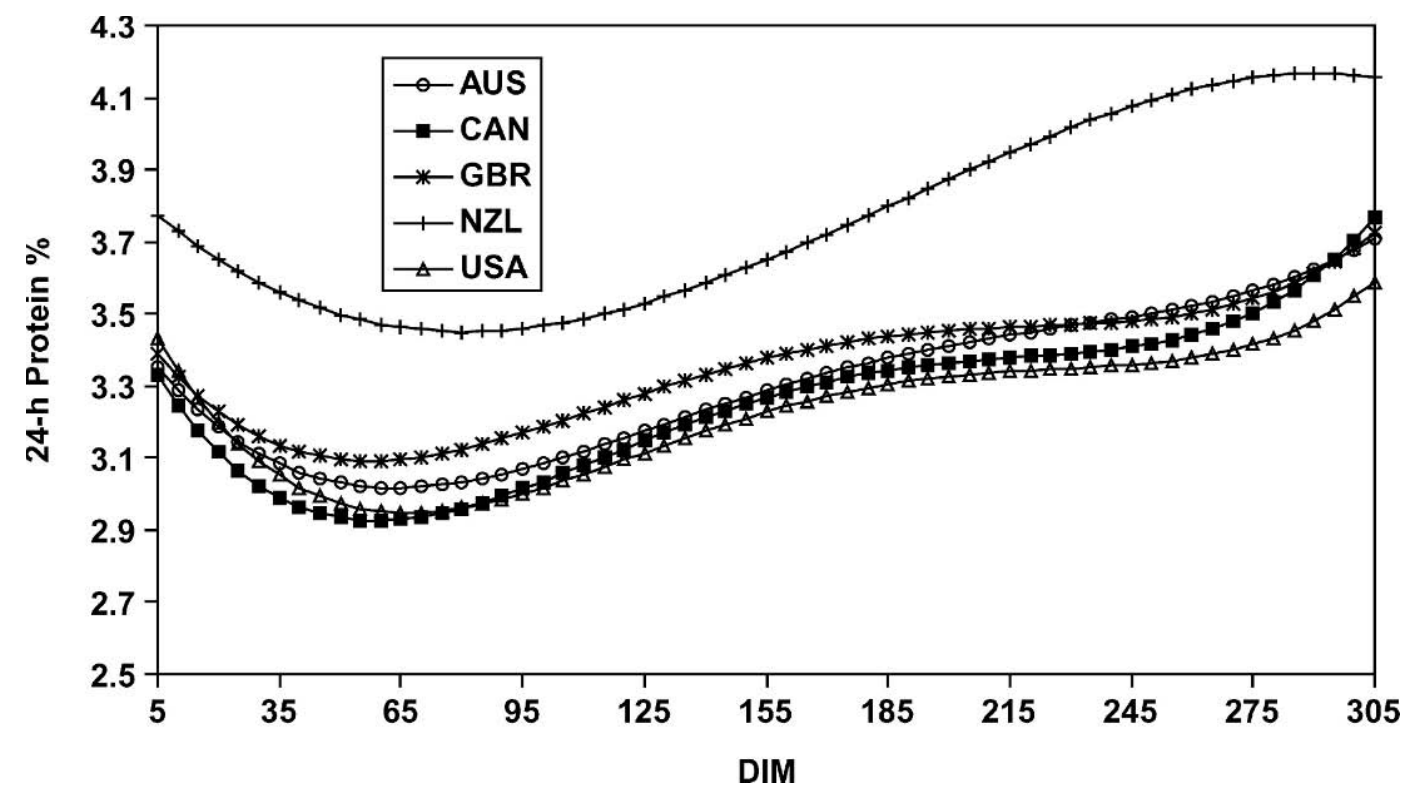

Figure 2. Lactation curves for protein percentage by DIM in first lactation for the 5 countries. AUS = Australia; CAN = Canada; GBR = Great Britain; NZL = New Zealand; USA = United States.

very similar in shape and level, with the United States having a slightly later day of peak yield. Australia had smaller yields, but higher persistency than the other countries. New Zealand had a visibly unique curve, with a noticeable drop-off in production after approximately 100 DIM, until reaching a plateau at approximately 250 DIM. This was largely due to New Zealand's seasonal dairying production system under which most lactations were shorter than $250 \mathrm{~d}$. Only high-producing animals in genetically superior herds were milking until $305 \mathrm{~d}$. Lactation curves for protein percentage by DIM in first lactation (Figure 2) were of similar shape and magnitude for Australia, Canada, Great Britain, and United States. New Zealand had a visibly unique curve, with a much higher level than the other 4 countries, and a sharper increase in late lactation, reaching a plateau after $255 \mathrm{~d}$.

There were 66 sires with at least 5 daughters and granddaughters in at least 2 countries: 30 sires from the United States, 26 from Australia, 5 from New Zealand, 3 sires from Norway (NRF), and 2 sires from Canada, of which one was a Red Holstein. Three NRF sires and one Red Holstein were expected among the common sires, as these breeds have been used in genetic expansion programs in both the United States and Australia. There was also great variability in sire usage, as the United States had progeny from 57 of the 66 common sires, whereas Great Britain only had representation from 7 common sires. Number of common sires among countries is reported in Table 5.

\section{Single-Country Genetic Parameters}

Posterior means for average daily heritabilities and genetic correlations from single-country models for milk and protein yield are shown in Table 6. Australia had the lowest heritability for all 3 lactations for milk yield, with Canada and the United States having the highest heritabilities. Heritability noticeably increased from first to third lactation in Australia, whereas it decreased for Canada and remained similar for New Zealand, Great Britain, and the United States. There was a wide range of estimated genetic correlations, with a difference of 0.18 between Australia and the United States for the correlation between first and second lactation and an even wider range between first and third lactations, with a difference of 0.25 between Great Britain and the United States. This disparity of correlations and heritabilities may be caused by differences in production systems between countries, but also may be partly due to parity definition. Great Britain and Australia tended to have the lowest heritabilities and correlations among lactations. These were the 2 countries for which parity number had to be enforced by number of calvings and age in months at calving, as mentioned previously. The highest correlations were found between second and third lactation, with all correlations higher than 0.81 , and the range in values being much lower than for the other 2 correlations. Muir and Kistemaker (2003) recently estimated genetic parameters for production traits in Canadian Milking Shorthorns. 
Table 5. Sires in common between country pairs.

\begin{tabular}{lcclcr}
\hline & & & Great & New & \\
& Australia & Canada & Britain & Zealand & Average \\
\hline Australia & & & & & 19.25 \\
Canada & 22 & & & & 18.75 \\
Great Britain & 6 & 3 & 2 & & 5.75 \\
New Zealand & 13 & 72 & 7 & 6 & 6.00 \\
United States & 36 & & & & 22.75 \\
\hline
\end{tabular}

Heritability estimates for milk from Canada (current study) were slightly higher than those reported by Muir and Kistemaker (2003), with values of $0.42,0.41$, and 0.42 for the first, second, and third lactations, respectively. Genetic correlation estimates in the 2 studies were very similar. The test-day model from Muir and Kistemaker (2003) was equivalent to the model used in this study, with one exception. Muir and Kistemaker (2003) used a 4-trait multiple-lactation test-day model, whereas a single-trait multiple lactation test-day model was applied in the current study.

Heritability estimates for protein yield (Table 6) were on average slightly higher than for milk yield, but genetic correlations among lactations were markedly lower, especially for Australia, Great Britain, and New Zealand, with values as low as 0.42 . This may be due to the nature of dairy production in these countries. Milking Shorthorn breeders in these 3 countries are more likely to use pasture based or pastoral production systems, and less likely to feed many high energy supplements, and therefore milk composition may change greatly depending on the nature and quality of feed.
However, as illustrated in Figure 2, the only country with a noticeably different lactation curve for protein percentage was New Zealand. Canada and the United States had very similar genetic correlations between lactations for protein and milk yield. Similar to milk yield, average daily heritability estimates for protein yield from Canada (current study) were higher than values ( 0.41 for all 3 lactations) found by Muir and Kistemaker (2003). Genetic correlations for protein yield between the 2 studies were very similar.

\section{Multiple-Country Genetic Parameters}

Average daily heritabilities, posterior means, and standard deviations of genetic correlations for milk yield are shown in Table 7. Heritability estimates for Australia were very similar to those found by singlecountry estimation (Table 6). Canada, Great Britain, and the United States all had slightly increased estimates (+0.01 to 0.05), whereas estimates for New Zealand substantially increased $(+0.10$ to 0.13$)$ for all 3 lactations over estimates from the single-country

Table 6. Average daily heritabilities and genetic correlations between lactations for milk and protein yield in the five countries (single-country models).

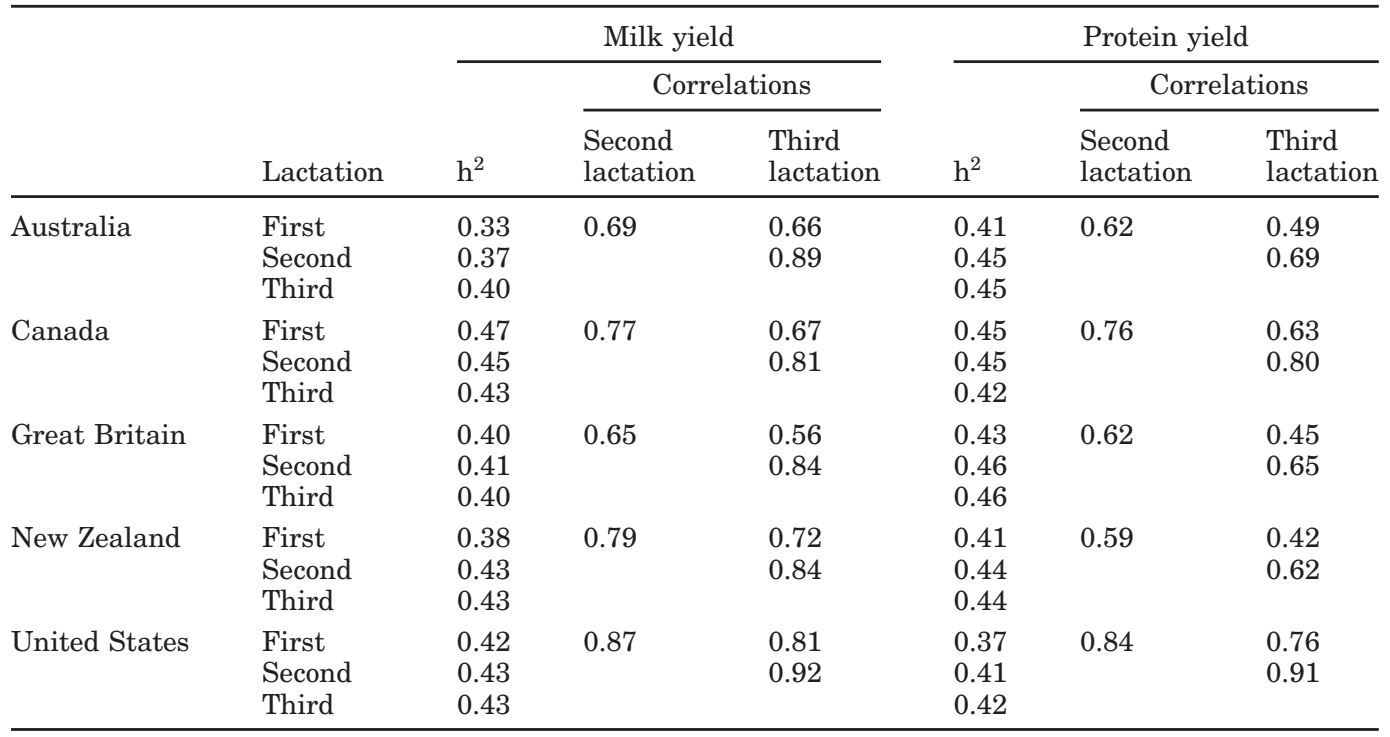


Table 7. Average daily heritabilities (in bold on diagonal), posterior means (above diagonal), and standard deviations (below diagonal) of genetic correlations for milk yield among 5 countries and 3 lactations.

\begin{tabular}{|c|c|c|c|c|c|c|c|c|c|c|c|c|c|c|c|c|}
\hline & Lactation & \multicolumn{3}{|c|}{ Australia } & \multicolumn{3}{|c|}{ Canada } & \multicolumn{3}{|c|}{ Great Britain } & \multicolumn{3}{|c|}{ New Zealand } & \multicolumn{3}{|c|}{ United States } \\
\hline Australia & $\begin{array}{l}1 \\
2 \\
3\end{array}$ & $\begin{array}{l}\mathbf{0 . 3 4} \\
0.03 \\
0.03\end{array}$ & $\begin{array}{l}0.66 \\
\mathbf{0 . 3 6} \\
0.03\end{array}$ & $\begin{array}{l}0.68 \\
0.71 \\
\mathbf{0 . 4 0}\end{array}$ & $\begin{array}{l}0.19 \\
0.13 \\
0.18\end{array}$ & $\begin{array}{l}0.25 \\
0.22 \\
0.28\end{array}$ & $\begin{array}{l}0.18 \\
0.15 \\
0.18\end{array}$ & $\begin{array}{l}0.20 \\
0.28 \\
0.24\end{array}$ & $\begin{array}{l}0.19 \\
0.27 \\
0.23\end{array}$ & $\begin{array}{l}0.24 \\
0.28 \\
0.25\end{array}$ & $\begin{array}{l}0.28 \\
0.28 \\
0.28\end{array}$ & $\begin{array}{l}0.24 \\
0.25 \\
0.25\end{array}$ & $\begin{array}{l}0.28 \\
0.23 \\
0.22\end{array}$ & $\begin{array}{l}0.37 \\
0.39 \\
0.39\end{array}$ & $\begin{array}{l}0.39 \\
0.41 \\
0.41\end{array}$ & $\begin{array}{l}0.33 \\
0.34 \\
0.34\end{array}$ \\
\hline Canada & $\begin{array}{l}1 \\
2 \\
3\end{array}$ & $\begin{array}{l}0.08 \\
0.09 \\
0.10\end{array}$ & $\begin{array}{l}0.09 \\
0.09 \\
0.09\end{array}$ & $\begin{array}{l}0.10 \\
0.10 \\
0.10\end{array}$ & $\begin{array}{l}\mathbf{0 . 5 2} \\
0.05 \\
0.06\end{array}$ & $\begin{array}{l}0.62 \\
\mathbf{0 . 4 7} \\
0.04\end{array}$ & $\begin{array}{l}0.57 \\
0.69 \\
0.42\end{array}$ & $\begin{array}{l}0.14 \\
0.10 \\
0.15\end{array}$ & $\begin{array}{l}0.16 \\
0.08 \\
0.14\end{array}$ & $\begin{array}{l}0.22 \\
0.11 \\
0.13\end{array}$ & $\begin{array}{l}0.19 \\
0.19 \\
0.22\end{array}$ & $\begin{array}{l}0.21 \\
0.19 \\
0.24\end{array}$ & $\begin{array}{l}0.21 \\
0.21 \\
0.22\end{array}$ & $\begin{array}{l}0.30 \\
0.41 \\
0.33\end{array}$ & $\begin{array}{l}0.30 \\
0.46 \\
0.36\end{array}$ & $\begin{array}{l}0.28 \\
0.44 \\
0.32\end{array}$ \\
\hline New Zealand & $\begin{array}{l}1 \\
2 \\
3\end{array}$ & $\begin{array}{l}0.08 \\
0.09 \\
0.09\end{array}$ & $\begin{array}{l}0.08 \\
0.09 \\
0.09\end{array}$ & $\begin{array}{l}0.08 \\
0.08 \\
0.08\end{array}$ & $\begin{array}{l}0.09 \\
0.09 \\
0.08\end{array}$ & $\begin{array}{l}0.08 \\
0.08 \\
0.09\end{array}$ & $\begin{array}{l}0.09 \\
0.10 \\
0.10\end{array}$ & $\begin{array}{l}0.10 \\
0.11 \\
0.12\end{array}$ & $\begin{array}{l}0.08 \\
0.09 \\
0.09\end{array}$ & $\begin{array}{l}0.10 \\
0.10 \\
0.11\end{array}$ & $\begin{array}{l}\mathbf{0 . 5 1} \\
0.03 \\
0.04\end{array}$ & $\begin{array}{l}0.72 \\
\mathbf{0 . 5 4} \\
0.03\end{array}$ & $\begin{array}{l}0.63 \\
0.75 \\
\mathbf{0 . 5 3}\end{array}$ & $\begin{array}{l}0.43 \\
0.43 \\
0.43\end{array}$ & $\begin{array}{l}0.43 \\
0.42 \\
0.42\end{array}$ & $\begin{array}{l}0.36 \\
0.35 \\
0.35\end{array}$ \\
\hline United States & $\begin{array}{l}1 \\
2 \\
3\end{array}$ & $\begin{array}{l}0.07 \\
0.08 \\
0.08\end{array}$ & $\begin{array}{l}0.07 \\
0.08 \\
0.08\end{array}$ & $\begin{array}{l}0.07 \\
0.08 \\
0.08\end{array}$ & $\begin{array}{l}0.07 \\
0.07 \\
0.08\end{array}$ & $\begin{array}{l}0.06 \\
0.08 \\
0.07\end{array}$ & $\begin{array}{l}0.07 \\
0.07 \\
0.08\end{array}$ & $\begin{array}{l}0.07 \\
0.07 \\
0.08\end{array}$ & $\begin{array}{l}0.08 \\
0.08 \\
0.08\end{array}$ & $\begin{array}{l}0.08 \\
0.09 \\
0.09\end{array}$ & $\begin{array}{l}0.07 \\
0.07 \\
0.07\end{array}$ & $\begin{array}{l}0.08 \\
0.08 \\
0.08\end{array}$ & $\begin{array}{l}0.08 \\
0.08 \\
0.08\end{array}$ & $\begin{array}{l}\mathbf{0 . 4 5} \\
0.02 \\
0.03\end{array}$ & $\begin{array}{l}0.81 \\
\mathbf{0 . 4 7} \\
0.02\end{array}$ & $\begin{array}{l}0.72 \\
0.83 \\
\mathbf{0 . 4 8}\end{array}$ \\
\hline
\end{tabular}

models. This increase in heritability may be due to the availability of additional data in the countries with smaller populations. Within-country correlations between lactations were approximately 0.10 lower than the corresponding correlations from single-country models, with the largest drop in estimates seen for Great Britain and Canada.

Between-country correlations were low (0.08 to 0.46 ) compared with values found in other breed studies (Table 7). In the most recent estimates of parameters for international evaluation (International Bull Evaluation Service, 2004), between-country correlations for the Ayrshire breed had a maximum value of 0.96 between the United States and Canada, and a minimum correlation of 0.77 between New Zealand and the United States (International Bull Evaluation Service,
2004). However, estimates derived from national repeatability models assume the genetic correlations among lactations to be unity. Similarly, Weigel et al. (2001) found correlations ranging from 0.77 to 0.96 on first-lactation records for Holsteins in 17 countries. Using a test-day model approach, Jamrozik et al. (2002b) found correlations among countries for milk production ranging from 0.66 to 0.83 for Holsteins in Australia, Canada, New Zealand, and Italy, but with only firstlactation records.

Genetic correlations with the United States for the other 4 countries were the highest, but the largest correlation was only 0.46 . Correlations tended to be the lowest for Canada with the other 4 countries, with the smallest correlation being only 0.08 between second lactation in Canada and second lactation in Great Brit-

Table 8. Correlations among estimated breeding values for milk yield for all animals between countries and between lactations.

\begin{tabular}{|c|c|c|c|c|c|c|c|c|c|c|c|c|c|c|c|c|}
\hline & Lactation & \multicolumn{3}{|c|}{ Australia } & \multicolumn{3}{|c|}{ Canada } & \multicolumn{3}{|c|}{ Great Britain } & \multicolumn{3}{|c|}{ New Zealand } & \multicolumn{3}{|c|}{ United States } \\
\hline Australia & $\begin{array}{l}1 \\
2 \\
3\end{array}$ & & 0.97 & $\begin{array}{l}0.95 \\
0.98\end{array}$ & $\begin{array}{l}0.68 \\
0.62 \\
0.60\end{array}$ & $\begin{array}{l}0.82 \\
0.82 \\
0.80\end{array}$ & $\begin{array}{l}0.80 \\
0.77 \\
0.74\end{array}$ & $\begin{array}{l}0.68 \\
0.65 \\
0.60\end{array}$ & $\begin{array}{l}0.74 \\
0.72 \\
0.67\end{array}$ & $\begin{array}{l}0.74 \\
0.71 \\
0.67\end{array}$ & $\begin{array}{l}0.51 \\
0.49 \\
0.43\end{array}$ & $\begin{array}{l}0.50 \\
0.48 \\
0.42\end{array}$ & $\begin{array}{l}0.51 \\
0.49 \\
0.43\end{array}$ & $\begin{array}{l}0.48 \\
0.44 \\
0.42\end{array}$ & $\begin{array}{l}0.58 \\
0.55 \\
0.53\end{array}$ & $\begin{array}{l}0.51 \\
0.46 \\
0.44\end{array}$ \\
\hline Canada & $\begin{array}{l}1 \\
2 \\
3\end{array}$ & & & & & 0.83 & $\begin{array}{l}0.89 \\
0.94\end{array}$ & $\begin{array}{l}0.62 \\
0.58 \\
0.61\end{array}$ & $\begin{array}{l}0.62 \\
0.62 \\
0.64\end{array}$ & $\begin{array}{l}0.59 \\
0.63 \\
0.64\end{array}$ & $\begin{array}{l}0.58 \\
0.54 \\
0.54\end{array}$ & $\begin{array}{l}0.52 \\
0.49 \\
0.49\end{array}$ & $\begin{array}{l}0.54 \\
0.52 \\
0.52\end{array}$ & $\begin{array}{l}0.46 \\
0.36 \\
0.46\end{array}$ & $\begin{array}{l}0.52 \\
0.46 \\
0.50\end{array}$ & $\begin{array}{l}0.56 \\
0.43 \\
0.50\end{array}$ \\
\hline New Zealand & $\begin{array}{l}1 \\
2 \\
3\end{array}$ & & & & & & & & & & & 0.87 & $\begin{array}{l}0.87 \\
0.95\end{array}$ & $\begin{array}{l}0.61 \\
0.62 \\
0.64\end{array}$ & $\begin{array}{l}0.69 \\
0.69 \\
0.71\end{array}$ & $\begin{array}{l}0.68 \\
0.68 \\
0.71\end{array}$ \\
\hline United States & $\begin{array}{l}1 \\
2 \\
3\end{array}$ & & & & & & & & & & & & & & 0.80 & $\begin{array}{l}0.78 \\
0.90\end{array}$ \\
\hline
\end{tabular}


Table 9. Country of origin of Top 100 sires for milk yield breeding values on the scale of each country.

\begin{tabular}{lcccccc}
\hline & \multicolumn{5}{c}{ Country scales } \\
\cline { 2 - 5 } $\begin{array}{l}\text { Country } \\
\text { of origin }\end{array}$ & Australia & Canada & $\begin{array}{l}\text { Great } \\
\text { Britain }\end{array}$ & $\begin{array}{l}\text { New } \\
\text { Zealand }\end{array}$ & $\begin{array}{c}\text { United } \\
\text { States }\end{array}$ & Average \\
\hline Australia & 76 & 76 & 14 & 26 & 52 & 48.8 \\
Canada & 11 & 11 & 17 & 11 & 9 & 11.8 \\
Great Britain & 1 & 1 & 44 & 6 & 12 & 12.8 \\
New Zealand & 0 & 0 & 4 & 37 & 7 & 9.8 \\
United States & 10 & 10 & 20 & 19 & 19 & 14.8 \\
Others & 2 & 2 & 1 & 1 & 1 & 2.0 \\
\hline
\end{tabular}

ain. In fact, correlations between Great Britain and Canada were equal to or only slightly higher than the standard deviations of the correlations. Low correlations for the Canadian population with the other countries may be due in part to the limited size of that country's contribution to the data.

Posterior standard deviations of estimated genetic correlations were largest for Great Britain. This may indicate that Great Britain had a variety of genetic lines with little connection with other populations, and might reflect the low within-country correlations found for that country. Standard deviations for between-country genetic correlations were only 0.03 to 0.05 using a test-day model in Jamrozik et al. (2002b), and similarly ranged from 0.01 to 0.06 using a lactation model in Weigel et al. (2001). The small number of common sires and extensive use of crossbreeding might be responsible for the substantially higher standard deviations of genetic correlations.

Alternative models were attempted to address the low between-country correlations in variance component estimation, which included a model with only a fixed regression, using only the intercept parameter from the Legendre polynomials, or varying the size of the subset for variance component estimation. In all model permutations, resulting estimates were even lower than those reported in this paper, so it was decided to remain with the model discussed within. Further research is needed to investigate possible alternatives to the model explored in this study, among those a) a repeatability lactation animal model, b) use of only first-lactation records, c) computing breeding values within country and including them in a MACE evaluation. However, results from any of the above strategies will be heavily affected by the current lack of genetic ties among countries present in the world Milking Shorthorn population.

\section{Breeding Value Estimation}

Correlations among EBV across lactations and across country scales (Table 8) were substantially higher than genetic correlations (Table 7). The highest correlations were between the United States and Canada, a likely reflection of a common genetic influence. Breeding value correlations ranged from 0.36 between secondlactation Canada and first-lactation Great Britain, to 0.82 between second lactation for both United States and Canada. It should be noted that breeding values correlations over time might be biased upwards in the presence of genetic trends. Breeding value correlations estimated in this study did not account for time trends.

On each country's scale, listings of Top 100 sires for milk breeding values were generated, with EBV averaged across lactations. The largest contributor of sires over all lists was made by Australian sires at 48.8 sires, over 3 times the contribution of the next largest contributor, the United States, with 14.8 sires (Table 9). In comparing the similarity of list composition by sire between the 5 Top 100 lists, the lists for the American and Australian country scales had the biggest similarity with 50 sires, and the British and Australian lists had the least similarity with only 20 sires in common (Table 10).

Average estimated breeding values for milk yield (expressed in standard deviation units) are reported by year of birth in Figure 3 for cows with records from 1989 to 1998. For each cow, breeding values were first averaged across lactations, standardized on each country scale, and averaged across country scales. There was a distinct upward trend for each country, with Australia population being constantly superior over time than the other populations. Canada and Great Britain achieved the largest yearly genetic progress during this period with 0.112 and 0.105 standard devia-

Table 10. Number of sires in common between Top 100 sires for milk yield breeding values on the scale of each country.

\begin{tabular}{lllll}
\hline & & Great & New & United \\
& Canada & Britain & Zealand & States \\
\hline Australia & 29 & 20 & 35 & 50 \\
Canada & & 22 & 27 & 41 \\
Great Britain & & & 40 & 34 \\
New Zealand & & & & 48 \\
\hline
\end{tabular}




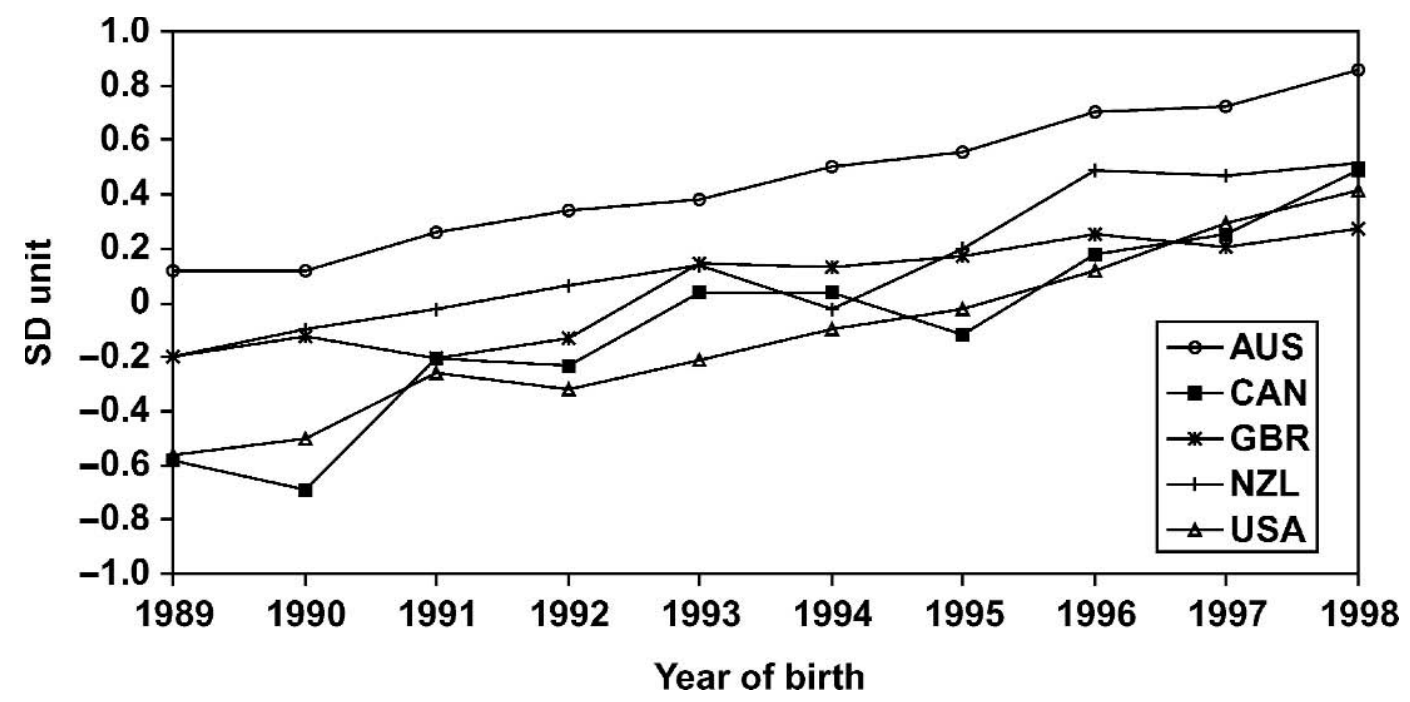

Figure 3. Average estimated breeding values for milk yield by country and year of birth for cows with records (expressed in standard deviation units). AUS = Australia; CAN = Canada; GBR = Great Britain; NZL = New Zealand; USA = United States.

tion units, respectively. Annual genetic progress was lower for the other populations, 0.08, 0.084, and 0.059 for United States, Australia, and New Zealand, respectively.

Although Australia was shown to be genetically superior over time, cows in this country had the second lowest phenotypic average for milk yield. Likewise, cows in New Zealand and the United States had similar genetic levels, but had the worst and best phenotypic average for milk yields, respectively. These differences between genetic level and phenotypic performance are due to differences in production systems. Although 2 countries may have similar genetic potentials in their populations, the production environment in one may be more limiting (i.e., grazing), and therefore expression in phenotype should be markedly different.

\section{CONCLUSIONS}

A multiple-country, multiple-lactation test-day animal model may not be the most appropriate method for joint evaluation of Milking Shorthorns at this time, due to lack of genetic ties, small contemporary group sizes, and possible over-parameterization of the model in relation to the size, structure, and completeness of available data. Single-country correlations between lactations varied greatly among countries, whereas multiplecountry correlations were much lower than values from related studies. Increasing genetic trends over time seem to indicate that genetic improvement is taking place in each of the 5 countries. A fully cross-referenced international pedigree file for Milking Shorthorn was constructed for the first time, and considerable informa- tion was gathered on the national populations, and their pedigree interconnections. Variance components for 5 countries were estimated for the first time for Milking Shorthorns. Increased international sampling of Milking Shorthorns is currently underway, with connections expected to increase substantially in the near future. Future evaluation with increased genetic ties among countries may more easily facilitate international comparison of Milking Shorthorns.

\section{ACKNOWLEDGMENTS}

Funding is deeply acknowledged from Canadian NSERC, American Milking Shorthorn Society, UK Shorthorn Society, Canadian Milking Shorthorn Society, the World Shorthorn Congress, and the Canadian Dairy Network (DairyGen). Thanks to individual genetic evaluation centers for providing data for the project.

\section{REFERENCES}

Banos, G., and C. Smith. 1991. Selecting bulls across countries to maximize genetic improvement in dairy cattle. J. Anim. Breed. Genet. 108:174-181.

Fikse, W. F. 2002. Merits of international genetic evaluations using performance records. Proc. 7th World Congr. Genet. Appl. Livest. Prod., Montpelier, France. XXIX:91-94.

International Bull Evaluation Service. 2004. INTERBULL routine genetic evaluation for production traits, May 2004. Online. Available http://www-interbull.slu.se. Accessed June 9, 2004.

Jamrozik, J., L. R. Schaeffer, and K. A. Weigel. 2002a. Genetic evaluation of bulls and cows with single and multiple-country test-day models. J. Dairy Sci. 85:1617-1622.

Jamrozik, J., L. R. Schaeffer, and K. A. Weigel. 2002b. Estimates of genetic parameters for single- and multiple-country test-day models. J. Dairy Sci. 85:3131-3141. 
Lohuis, M. M., and J. C. M. Dekkers. 1998. Merits of borderless evaluations. Proc. 6th World Congr. Genet. Appl. Livest. Prod., Armidale, Australia. XXVI:169-172.

Muir, B., and G. J. Kistemaker. 2003. Estimation of genetic parameters for the Canadian test-day model with Legendre polynomials for coloured breeds based on more recent data. Online. Available http://www.cdn.ca/committe.htm. Accessed Nov. 11, 2004.

Pedersen, J., U. S. Nielsen, G. P. Aamand, J. Pösö, E. Mäntysaari, M. Lidauer, I. Stranden, P. Madsen, and K. Johansson. 2004 Joint Nordic test-day model for milk production traits. Interbull Bull. 32:8-12.
Schaeffer, L. R. 1994. Multiple-country comparison of dairy sires. J. Dairy Sci. 77:2671-2678.

Schaeffer, L. R., J. Jamrozik, G. Kistemaker, and B. J. Van Doormaal. 2000. Experience with a test-day model. J. Dairy Sci. 83:11351144.

Sullivan, P. G. 2002. Genetic evaluation strategies for multiple-traits and countries. Ph.D. Diss. University of Guelph, Ontario, Canada.

Weigel, K. A., R. Rekaya, N. R. Zwald, and W. F. Fikse. 2001. International genetic evaluation of dairy sires using a multiple-trait model with individual animal performance records. J. Dairy Sci. 84:2789-2795. 